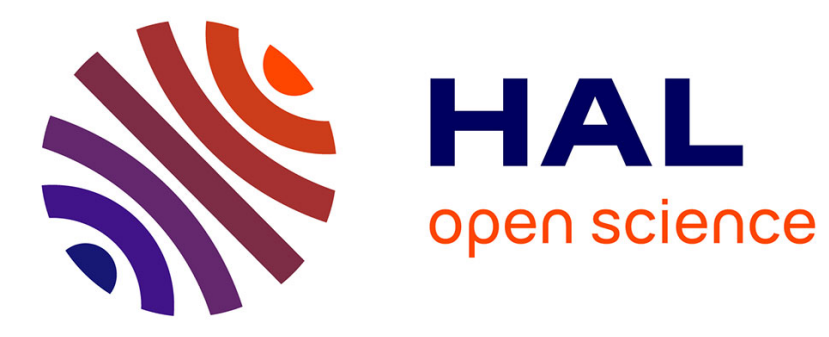

\title{
Speciation of residual carbon contained in $\mathrm{UO}_{-} 2$ \\ Yannis Ziouane, Bénédicte Arab-Chapelet, Christelle Tamain, Sophie Lalleman, Thibaud Delahaye, Gilles Leturcq
}

\section{To cite this version:}

Yannis Ziouane, Bénédicte Arab-Chapelet, Christelle Tamain, Sophie Lalleman, Thibaud Delahaye, et al.. Speciation of residual carbon contained in UO_2. Journal of Solid State Chemistry, 2016, 244, pp.45-51. 10.1016/j.jssc.2016.09.003 . cea-02389158

\section{HAL Id: cea-02389158 https://hal-cea.archives-ouvertes.fr/cea-02389158}

Submitted on 2 Dec 2019

HAL is a multi-disciplinary open access archive for the deposit and dissemination of scientific research documents, whether they are published or not. The documents may come from teaching and research institutions in France or abroad, or from public or private research centers.
L'archive ouverte pluridisciplinaire HAL, est destinée au dépôt et à la diffusion de documents scientifiques de niveau recherche, publiés ou non, émanant des établissements d'enseignement et de recherche français ou étrangers, des laboratoires publics ou privés. 
Yannis ZIOUANE ${ }^{\text {a }}$, Bénédicte ARAB-CHAPELET ${ }^{\mathrm{b}}$, Christelle TAMAIN $^{\mathrm{c}}$, Sophie LALLEMAN ${ }^{\mathrm{a}}$, Thibaud DELAHAYE $^{\mathrm{b}}$, Gilles LETURCQ ${ }^{\mathrm{a}}$

${ }^{\text {a }}$ CEA, Nuclear Energy Division, RadioChemistry \& Processes Department, SERA, LED, F-30207 Bagnols sur Cèze, France

${ }^{\mathrm{b}}$ CEA, Nuclear Energy Division, RadioChemistry \& Processes Department, SERA, LCAR, F-30207 Bagnols sur Cèze, France

${ }^{c}$ CEA, Nuclear Energy Division, RadioChemistry \& Processes Department, SMCS, LILA, F-30207 Bagnols sur Cèze, France

\section{Speciation of residual carbon contained in $\mathrm{UO}_{2}$}

\section{Corresponding author:}

E-mail address: gilles.leturcq@cea.fr (G.LETURCQ)

Full postal address: CEA Marcoule, bât 166. 30207 Bagnols-sur-Cèze Cédex

\section{Keywords}

$\mathrm{UO}_{2}$, residual carbon, dissolution kinetics

\section{Abstract}

$\mathrm{UO}_{2}$ powders were synthesized thanks to oxalic precipitation (platelet morphology) and sol-gel route and completely characterized. A secondary phase was found in addition of the oxide depending on the calcination atmospheres. This phase has been identified by Raman spectroscopy as graphitic material (i.e. carbon-based secondary compound) and quantified by thermogravimetric analyses. Its amount varies with the calcination atmosphere. The presence of this secondary phase has no significant effect on the lattice parameter and its specific surface area. 


\section{Introduction}

One well-known method to synthesize actinide oxides is the thermal treatment of actinide oxalates under controlled atmosphere [1]. Calcinations under oxygen deficient atmospheres permit to avoid over-oxidation of the final oxide. Such controlled treatments lead to actinide dioxides presenting a targeted O/M (stoichiometry of oxygen / metal) ratio close to 2.00 and usually integrating residual carbon still remaining [2,3]. Depending on the conversion conditions (heating rate / maximum temperature / atmosphere), this carbon content varies from a few ppm to about 0.42 at. \% [4]. Up to now, this secondary phase remains uncharacterized and additional investigations are required to fully identify its structure. As a first approach, such characterizations of the residual carbon have been carried out on $\mathrm{UO}_{2}$ synthesized in similar conditions (i.e. using oxalic conversion). For comparison purposes, $\mathrm{UO}_{2}$ powder was also synthesized using a sol-gel route for which another amount of residual carbon is observed.

\section{Experimental section}

\subsection{Synthesis of $\mathrm{UO}_{2}$ powders}

\subsubsection{Oxalic synthesis route}

The oxalic conversion is usually reported to synthetize actinide oxides [5,6]. This process is based on an oxalic precipitation followed by a calcination step under controlled atmosphere. In this study, $\mathrm{UO}_{2}$ is obtained by uranium (IV) oxalic precipitation. In details, uranium (IV) solution was prepared by catalytic reduction of uranium (VI) nitrate by $\mathrm{H}_{2}$ on a $\mathrm{Pt} / \mathrm{Si}$ support. Hydrazinium nitrate $\left(\mathrm{N}_{2} \mathrm{H}_{5}{ }^{+}\right)$was used as an anti-nitrous agent to stabilize the uranium to its lowest oxidation states (i.e. +IV). The uranium precipitate was obtained by mixing oxalic acid and the $U$ (IV) solution. Concentrations were fixed in order to reach in the precipitator a final concentration of nitric acid equal to $2 \mathrm{M}$ and an oxalic excess of $0.05 \mathrm{M}$. In this conditions, tetravalent actinides form an oxalate of formula $\mathrm{An}^{\mathrm{IV}}\left(\mathrm{C}_{2} \mathrm{O}_{4}\right)_{2} \cdot 6 \mathrm{H}_{2} \mathrm{O}$ [7]. This oxalate has a monoclinic structure and crystallizes as agglomerate square-plates [8]. Obtained-precipitate was filtered off and rinsed with a water/ethanol mixture (10/90) before being air dried.

\subsubsection{Sol-gel route}

Articles referring to the sol-gel method lead to the synthesis of microspheres $[9,10]$. In this paper, to synthesize powders, protocols were modified as follows. A $1.7 \mathrm{M} \mathrm{U}(+\mathrm{VI})$ monometallic nitrate solution was obtained through dissolution of uranyl nitrate $\mathrm{UO}_{2}\left(\mathrm{NO}_{3}\right)_{2}$ in pure water. This metal nitrate solution was mixed with urea $\left(\mathrm{CO}\left(\mathrm{NH}_{2}\right)_{2}\right)$ and HMTA (hexamethylenetetramine) solution at low temperature $\left(\sim 5^{\circ} \mathrm{C}\right)$. Urea acts as a complexing agent of $\mathrm{U}(\mathrm{VI})$ preventing from premature precipitation of this cation when HMTA is added. The ratio [urea] / [U] and [HMTA] / [U] used was respectively 1.74 and 1.71. Once urea and HMTA were dissolved into the cold uranyl solution, the solution was stirred and heated at $80^{\circ} \mathrm{C}$. HMTA was decomposed at high temperature causing an increase in $\mathrm{pH}$ and hydrolysis of uranium. In few minutes, solution jellified. At room temperature, this gel was washed with $\mathrm{NH}_{4} \mathrm{OH}$ allowing the elimination of the remaining organic matter provided by the reagents. The washed gel of $\mathrm{UO}_{3}$ was dried at $250^{\circ} \mathrm{C}$ for 20 hours to remove residual ammonium nitrate and moisture.

\subsubsection{Thermal treatments}

Thermal treatments were performed for all precursors (oxalate and $\mathrm{UO}_{3}$ ) up to $1127 \mathrm{~K}$ with a heating rate of 20 K. $\min ^{-1}$. Compounds were maintained at this temperature for $90 \mathrm{~min}$ then cooled down to room temperature. Different calcination atmospheres were used in order to obtain in all cases $\mathrm{UO}_{2}$ powders. Considering oxalate powder, it was then divided into two equal batches: one was calcined under reducing atmosphere $\mathrm{Ar} / \mathrm{H}_{2}(96 / 4)$ and the other one was calcined firstly in oxidizing atmosphere followed by the same calcination under reducing conditions $\mathrm{Ar} / \mathrm{H}_{2}(96 / 4)$. The $\mathrm{UO}_{3}$ gel was calcined under $\mathrm{Ar} / \mathrm{H}_{2}(96 / 4)$. 


\subsection{Characterization}

\subsubsection{XRD Analysis}

XRD (X-Ray Diffraction) analyses of the synthesized powders were performed using a D8 Bruker Advance diffractometer (LynxEye detector) using $\mathrm{Cu}-\mathrm{K} \alpha$ radiation $(\lambda=1.5418 \AA$ ) especially equipped for radioactive material measurements. Gold was added as an internal standard to calibrate the angular positions of the observed XRD lines. Each powder pattern was recorded within an angular range from $5^{\circ}$ to $80^{\circ}$ in 2 theta, with steps of $0.02^{\circ}$ and a counting time of $0.6 \mathrm{~s}$ per step. The lattice parameters were determined by Le Bail refinement using the TOPAS software (TOtal Pattern Analysis Solutions) from BRUKER AXS [11] where only the profile parameters (cell dimensions, peak shapes, background, zero point correction) were refined. The microstrains and average crystallite sizes were calculated with the fundamental parameters method [12]. The percent of microstrains in a structure can increase with incorporation of impurities in the cell or substitution of atoms.

\subsubsection{Specific surface area measurements}

$\mathrm{N}_{2}$ adsorption-desorption isotherm was measured at the boiling point of nitrogen $\left(-196{ }^{\circ} \mathrm{C}\right)$ using a Micromeritics Gemini 2375 equipment. The amount of adsorbed gas is correlated to the total specific surface area of the particles including pores in the surface. The specific surface area was calculated by the BrunauerEmmett-Teller (BET) 5 points method [13] from around $1 \mathrm{~g}$ of each powder.

\subsubsection{SEM Observations}

A scanning electron microscope (SEM) available in ATALANTE facility was used: a JEOL T 330A, installed in a hot cell $(8 \mathrm{~cm}$ steel) for highly radioactive samples, allows secondary electron imaging. Previously, samples were deposited on a carbon substrate, and then metallized with gold for $4 \mathrm{~min}$.

\subsubsection{Raman spectra}

A Horiba Jobin-Yvon LabRam HR Evolution Raman spectrometer was used in conjunction with a nuclearized superhead (Optique Peter, Lyon, France) mounted on a support with an objective turret $(10 \times, 20 \times$ and $50 \times)$. A YAG laser $(532 \mathrm{~nm}$ ) with output power adjustable from 0.5 to $100 \mathrm{~mW}$ was used to provide low-excitation-beam power levels. The superhead was mounted in glove box, while the Raman spectrometer and laser were installed outside with a fiber-optic signal transmission line. The microscope objective used was $20 \times$ and the acquisition time was $1200 \mathrm{~s}$. Raman spectra were obtained from $20 \mathrm{mg}$ samples. The beam has a diameter equal to $2 \mu \mathrm{m}$. Contrary to what has been previously observed by Tyrpekl et al. [14], the laser intensity was sufficiently low to avoid an oxidizing of $\mathrm{UO}_{2}$ to $\mathrm{U}_{3} \mathrm{O}_{8}$ or $\mathrm{UO}_{3}$ compounds.

\subsubsection{TGA- $\mu \mathrm{GC}$}

The ratio of residual carbon remaining in the powder after calcination was estimated by thermogravimetric analysis (TGA) coupled with gas chromatography measurements ( $\mu$ GC). Analyses (Netzsch STA 449 thermogravimetric analyzer) were carried out on samples under air up to $1000^{\circ} \mathrm{C} . \mathrm{CO}_{2}$ and $\mathrm{CO}$ releases were monitored. Approximately $50 \mathrm{mg}$ of powder were used per analysis to obtain a representative value of residual carbon in the samples.

\subsubsection{Dissolution}

All the dissolutions described in this work consisted in dissolving $300 \mathrm{mg}$ of synthetized $\mathrm{UO}_{2}$ powder in $15 \mathrm{~mL}$ of nitric acid $1.5 \mathrm{~mol} . \mathrm{L}^{-1}$. Solution was stirred at $300 \mathrm{rpm}$ and maintained at $323.15 \mathrm{~K} .1 \mathrm{~h}$ static dissolutions were performed in a batch of $20 \mathrm{~mL}$. The aim of these dissolution experiments was to isolate the residual carbon of our powders. In addition, the different dissolution kinetics were also recorded using UV-visible spectroscopy. The device used was a Varian Cary 50 from Agilent Technologies. Dissolution of $\mathrm{UO}_{2}$ in nitric media consisted 
in oxidizing $\mathrm{U}(+\mathrm{IV})$ to $\mathrm{U}^{+\mathrm{VI}} \mathrm{O}_{2}\left(\mathrm{NO}_{3}\right)_{2}$ [15]. In $\mathrm{UV}$-visible spectroscopy, the band of the $\mathrm{U}(+\mathrm{VI})$ present in solution appears near $415 \mathrm{~nm}$. From pre-established standards and the Beer-Lambert law, it is possible to convert the absorbance into concentration of uranium (VI) in solution. A $10 \%$ error bar has to be applied to experimental concentration data due to the use of optical fibers and the range of analyzed concentrations (i.e. from 2 to $\left.18 \mathrm{~g} . \mathrm{L}^{-1}\right)$.

\section{Results and discussion}

\subsection{Influence of carbon presence on $\mathrm{UO}_{2}$ structure}

\subsubsection{Structural description}

The oxalate $\mathrm{U}\left(\mathrm{C}_{2} \mathrm{O}_{4}\right)_{2} \cdot 6 \mathrm{H}_{2} \mathrm{O}$ precipitate was divided in two batches calcined in two different atmospheres : Ar/ $\mathrm{H}_{2}$ (96/4) and Air $+\mathrm{Ar} / \mathrm{H}_{2}(96 / 4)$ in a two-step calcination process. For both compounds, the XRD patterns of powders correspond to a sole fluorite-type $\mathrm{UO}_{2}$ structure. Within the XRD detection limits, there are thus no additional phases. Table 1 gathers structural parameters of the different uranium oxides and the associated specific surface area (measured by BET method). A variation of lattice parameters and lattice volume with the calcination atmosphere is observed. Concerning oxide obtained after a double calcination, this post-calcination evolution of lattice parameter is explained by a slight sur-stoichiometry of the compound which results from the calcination in air $+\mathrm{Ar} / \mathrm{H}_{2}$. This oxygen over-stoichiometry can be explained by the former formation of $\mathrm{U}_{3} \mathrm{O}_{8}$ [16] $(\mathrm{O} / \mathrm{U}=2.67)$ when compound was firstly calcined in flowing air and the difficulty to obtain a perfect stoichiometry (i.e. 2.00) during the second calcination in reductive atmosphere $\mathrm{Ar} / \mathrm{H}_{2} . \mathrm{UO}_{2}$ obtained by sol-gel route has a lattice parameter close to the perfect value (i.e. 5.471). Similar lattice parameter was obtained for the $\mathrm{UO}_{2}$ synthesized after calcination in $\mathrm{Ar} / \mathrm{H}_{2}$ atmosphere of the oxalate.

Concerning the powder obtained after a single calcination of the oxalate, crystallite sizes determined from the XRD diagram are about $160 \mathrm{~nm}$. In the case of the double calcination air $+\mathrm{Ar} / \mathrm{H}_{2}$, this value is multiplied by 2 . This bigger crystallite size is due to the crystalline growth with the calcination time [17]. Indeed, $\mathrm{UO}_{2}$ resulted from the double calcination has undergone a calcination time twice longer than the $\mathrm{UO}_{2}$ obtained after a single calcination.

Despite these different crystallite sizes, the specific surface areas, determined by BET method, were similar for both $\mathrm{UO}_{2}$ obtained by oxalic conversion and equal to $1 \mathrm{~m}^{2} / \mathrm{g}$. The specific surface area is higher in the case of the oxide made by sol-gel route $\left(2 \mathrm{~m}^{2} / \mathrm{g}\right)$, which can be explained by its different morphology (cf 3.1.4). This difference in specific surface areas may explain the better reduction of $\mathrm{UO}_{3}$ leading to a perfect $\mathrm{UO}_{2}$ in the case of the oxide made by sol-gel route compared to the slight oxygen sur-stoichiometry of the $\mathrm{UO}_{2}$ obtained by the double calcination of oxalate (reduction of $\mathrm{U}_{3} \mathrm{O}_{8}$ ) due to an higher reactivity of the calcination gas in the case of the sol-gel precursor.

The microstrains of the synthetized oxides were similar. Indeed, in the case of the both single calcination, the value of microstrains were close to $0.10 \%$ and this value is equal to $0.6 \%$ in the case of the powder obtained after a time of calcination twice longer. 


\begin{tabular}{c|c|c|c|c}
\hline Precursors route & $\begin{array}{c}\text { Oxalate } \\
\text { single calcination }\end{array}$ & \multicolumn{2}{|c|}{$\begin{array}{c}\text { Oxalate } \\
\text { double calcination }\end{array}$} & $\begin{array}{c}\text { Sol-gel } \\
\text { single calcination }\end{array}$ \\
\hline Calcination atmosphere & $\mathrm{Ar} / \mathrm{H}_{2}(96 / 4)$ & $\mathrm{Air}$ & $\mathrm{Ar} / \mathrm{H}_{2}(96 / 4)$ & $\mathrm{Ar} / \mathrm{H}_{2}(96 / 4)$ \\
Bearing time at $1127 \mathrm{~K}(\mathrm{~min})$ & 90 & 90 & 90 & 90 \\
\hline Lattice parameter $(\AA)$ & $5.4704(1)$ & \multicolumn{2}{|c|}{$5.4686(1)$} & $5.4694(1)$ \\
Lattice volume $\left(\AA^{3}\right)$ & $163.7(1)$ & \multicolumn{2}{|c|}{$163.5(1)$} & $163.6(1)$ \\
Average crystallite sizes $(\mathrm{nm})$ & $167(3)$ & \multicolumn{2}{|c|}{$351(7)$} & $164(2)$ \\
$\mathrm{Rp}(\%)$ & 7.97 & 7.22 & 3.63 \\
$\mathrm{Rwp}(\%)$ & 10.21 & 9.06 & 4.59 \\
$\mathrm{GOF}$ & 3.86 & 3.68 & 1.89 \\
Microstrain $(\%)$ & $0.0977(45)$ & $0.0651(25)$ & $0.1036(37)$ \\
Specific surface area $\left(\mathrm{m}^{2} / \mathrm{g}\right)$ & $1 \pm 0.2$ & $1 \pm 0.2$ & $2 \pm 0.2$ \\
\hline
\end{tabular}

\subsubsection{Raman spectra}

After dissolution of the $\mathrm{UO}_{2}$ powder obtained by calcination of oxalate in $\mathrm{Ar} / \mathrm{H}_{2}$ atmosphere, some non-soluble black particles remained in the nitric acid solution whereas UV-spectroscopy showed that all uranium present in the starting oxide was dissolved. This solid phase was collected by filtration and analyzed through Raman spectroscopy. Four bands characteristic of a graphitic material [18] are visible on the spectrum (figure 1). One of the main bands at $1350 \mathrm{~cm}^{-1}$ corresponds to the D-band (D for defect or disorder) and is commonly present for all $\mathrm{sp}^{2}$ carbon systems. This band is absent for graphene perfect structures [19]. Another intense band distinctive of C-C bonds in graphitic materials in presence of impurities appears at $1620 \mathrm{~cm}^{-1}$. This D'-band cannot exist without the previous one and has a weaker intensity [20]. This band is generated by the splitting of a band at $1583 \mathrm{~cm}^{-1}$ into two vibration modes [21]: one D' - band at $1620 \mathrm{~cm}^{-1}$ and one $\mathrm{G}-$ band at $1583 \mathrm{~cm}^{-1}$, due to the presence of impurities which interact with the band of graphene. The $\mathrm{G}$ - band refers to the fingerprint of singlelayered graphene. On figure 1, the $\mathrm{G}$ - band is not visible probably hidden by the other broad signal. The band at $2680 \mathrm{~cm}^{-1}$ is called G'-band or $2 \mathrm{D}-$ band and is an overtone of the $\mathrm{G}-$ band [22]. In the case of graphene materials, the intensity of the $\mathrm{G}^{\prime}$ - band is supposed to be higher or equal to the intensity of the band at $1583 \mathrm{~cm}^{-1}$ [23]. The small intensity at $2680 \mathrm{~cm}^{-1}$ explains the fact that the band at $1583 \mathrm{~cm}^{-1}$ is hidden by the wide $\mathrm{D}^{\prime}$ band in the $1500-1750 \mathrm{~cm}^{-1}$ range. The band at $2947 \mathrm{~cm}^{-1}$ is also reported as D+G mode for graphitic materials and Bokobza et al. [24] explain that its intensity increases with the amount of disorder. Therefore, according to the Raman spectroscopy, the black residual solid collected after dissolution is a graphitic phase containing impurities and presenting some crystallographic defects. This material could result from the thermal decomposition of oxalate generating carbon monoxide and its disproportionation according to equation 3.1 [25].

$2 \mathrm{CO}(g) \rightarrow \mathrm{CO}_{2}(g)+C(s)$

Eq 3.1

$\mathrm{UO}_{2}$ samples analyzed by Raman spectroscopy are illustrated in figure 1 and present characteristics bands at 445 $\mathrm{cm}^{-1}$ typical of the fluorite $\mathrm{UO}_{2}$ structure, attributed to the triplet degenerated T2g Raman-active vibration [26]. Another band at $575 \mathrm{~cm}^{-1}$ is described as the "fingerprint" of the quasi-perfect fluorite structure [27], its intensity is linked to the presence of oxygen vacancies in the fluorite structure [28]. The most intense band at $1150 \mathrm{~cm}^{-1}$ corresponds to an overtone of the precedent one [29]. The comparison of the two $\mathrm{UO}_{2}$ powders obtained with oxalic route reveals an increase in intensity of the 445 and $1150 \mathrm{~cm}^{-1}$ bands and a decrease in intensity of the 575 $\mathrm{cm}^{-1}$ for the oxide synthesized after a single calcination. This phenomenon is characteristic of a deviation from the perfect cubic structure [30] due to over-oxidation. It confirms data obtained by XRD analyses concerning the little over-oxidation (i.e. $\mathrm{O} / \mathrm{U}=2.02$ ) of $\mathrm{UO}_{2}$ from double calcination. For both this samples, the characteristic bands of the previously described graphitic phase (i.e. 1350 and $1615 \mathrm{~cm}^{-1}$ ) appear and an evolution is observed with the calcination atmosphere. Band intensities are highest for the single calcination under $\mathrm{Ar} / \mathrm{H}_{2}(96 / 4)$ sample. A dozen of spectra were recorded on both samples showing a variation of the ratio of the intensities of bands $1375 \mathrm{~cm}^{-1}$ (carbon phase) and $1150 \mathrm{~cm}^{-1}\left(\mathrm{UO}_{2}\right.$ phase) according to the area under consideration. This ratio is in a range between 0.69 and 0.51 in the case of the sample which undergone a simple calcination under $\mathrm{Ar} / \mathrm{H}_{2}$ (96/4). For the second sample, this ratio varies from 0.37 to 0.20 . The average ratio for simple calcination and double calcination $\mathrm{UO}_{2}$ are respectively 0.62 and 0.28 . This evolution allows concluding about a heterogeneous distribution of the carbon phase in both samples and a highest inclusion of carbon when oxalate is calcined only in $\mathrm{Ar} / \mathrm{H}_{2} . \mathrm{UO}_{2}$ obtained by sol-gel method was also analyzed; the typical spectra of $\mathrm{UO}_{2}$ were found and the 
presence of the graphitic material was again observed by Raman spectroscopy, it is however impossible to say if there is more or less carbon than the material obtained by oxalic route after an oxidizing/reducing calcination.

\subsubsection{ATG- $\mu \mathrm{GC}$}

Carbon content of $\mathrm{UO}_{2}$ powders was estimated by TGA- $\mu \mathrm{GC}$ analyses. As mentioned after the Raman investigation, the carbon content of powders synthesized by oxalic route is dependent on the calcination atmosphere. Two types of carbon were evidenced: a first peak emission appeared in the range of $250-650{ }^{\circ} \mathrm{C}$ corresponding to the elimination of the carbon included as $\mathrm{CO}_{2}$ absorbed on the powder. The second emission, between 650 and $1000^{\circ} \mathrm{C}$, corresponds to the combustion of the graphitic carbon observed by Raman spectroscopy. Quantities of elemental carbon found by $\mu \mathrm{GC}$ are $0.12 \mathrm{w} . \%$ and $0.07 \mathrm{w} . \%$ for the single and the double calcination respectively. The ratio between these two values is close to the value found by Raman spectroscopy (i.e. 0.62 compared to 0.28 ). The carbon dioxide signature band at $1480 \mathrm{~cm}^{-1}$ [31] was observed for any of the three $\mathrm{UO}_{2}$ by Raman spectroscopy due to the weak presence on the surface of oxides and a weaker Raman response of this phase. Moreover, this band may be hidden by both the intense graphitic bands at 1350 and $1615 \mathrm{~cm}^{-1}$. In the case of the oxide obtained via the sol-gel route, the quantity of elemental carbon was 0.11 w.\%. This carbon comes from the decomposition of organic compounds (urea and HMTA), which were not totally eliminated during the washing step.

\subsubsection{Powder morphologies}

SEM micrographs in figure 2 present the powder morphology of the different uranium oxides. The powder obtained by sol-gel route is composed of one to four hundred micrometers agglomerates of particles measuring several hundred nanometers in diameter. Concerning oxides obtained by oxalic route, morphologies obtained were agglomerates of square-plates. The square-plate sizes are exactly the same for both compounds and vary between 4 and $8 \mu \mathrm{m}$. Differences are observed at the level of the crystallite size. For the compound formed after single calcination, crystallite sizes ranging from 150 to $400 \mathrm{~nm}$ are observed, while for the oxide obtained after a double calcination crystallites have a size ranging from 300 to $800 \mathrm{~nm}$. These values are in agreement with the data found by XRD analyses. It is observed for this last compound an intergranular porosity which can be due to the reduction of $\mathrm{U}_{3} \mathrm{O}_{8}$ to $\mathrm{UO}_{2}$ : indeed, $\mathrm{U}_{3} \mathrm{O}_{8}$ structure presents a $30 \%$ greater lattice volume than $\mathrm{UO}_{2}$ [32]. The porosity then induced could not be erased during this reductive calcination because of a too low temperature or a too short calcination time. An increase in porosity should induce an increase in the specific surface area. However, crystallite growth from the second calcination induces a decrease in the specific surface area. A competition between porosity and crystallite growth may then explain the similar values of specific surface areas of the two powders.

\subsubsection{Discussion on the effect of carbon content on $\mathrm{UO}_{2}$ characteristics}

Raman spectroscopy demonstrated the presence of two distinct phases heterogeneously distributed: a $\mathrm{UO}_{2}$ powder and a graphitic phase composed of carbon only. However, is the carbon totally present in this second phase, or is a part of this carbon present in the cell of the $\mathrm{UO}_{2}$ as crystal defects?

Assuming an incorporation of carbon into the $\mathrm{UO}_{2}$ structure would have an effect on the value of the lattice parameters and the microstrain rates, focusing on our structural parameters values (table 2) for different carbon contents may answer this question. It has already been published $[33,34]$ that there is a relation between an incorporation of atoms in a cell and the structural parameters calculated. Authors reported that an increase in the incorporation atom rate leads to an increase in the lattice parameters but also in the microstrain percent that is characteristic of a cell distortion or interparticle interactions. Weak microstrain values were obtained in all of the samples synthesized and the three values were close to the one of an ideal $\mathrm{UO}_{2}$ (i.e. with no microstrain in the $\mathrm{UO}_{2}$ cell). Therefore, it is possible to conclude that only a very small amount or none of the residual carbon would have entered inside the $\mathrm{UO}_{2}$ cell. However, a slight variation in microstrain rates between our three samples follows the same variation of the carbon content despite the fact that most of this carbon content forms the graphitic phase. Moreover, if an $\mathrm{O}$ sur-stoichiometry may have similar effect on the microstrain rates, it can be observed in the sample resulting from the double calcination and presenting the lowest lattice parameter (i.e. the biggest $\mathrm{O}$ sur-stoichiometry) the weakest microstrain rates. Therefore, such little $\mathrm{O}$ sur-stoichiometry seems to have no effect on microstrain rates. It is then possible to conclude that some of the residual carbon may have entered inside the $\mathrm{UO}_{2}$ cell but only a very little amount as all of the microstrain rates observed are very low. So far it has not been possible to quantify this amount. 
Oxide compounds resulting from oxalic route lead to the same specific surface area implying that the amount of carbon has no effect on this parameter. The difference in surface specific areas between $\mathrm{UO}_{2}$ obtained by sol-gel and oxalic route can be explained by their different morphologies.

Table 2 : Lattice parameters and carbon content of the $\mathrm{UO}_{2}$ powders

\begin{tabular}{c|c|c|c}
\hline Precursors route & $\begin{array}{c}\text { Oxalate } \\
\text { single calcination }\end{array}$ & $\begin{array}{c}\text { Oxalate } \\
\text { double calcination }\end{array}$ & $\begin{array}{c}\text { Sol-gel } \\
\text { single calcination }\end{array}$ \\
\hline Microstrains $(\%)$ & $0.0977(45)$ & $0.0651(25)$ & $0.1036(37)$ \\
\hline Lattice parameter $(\AA)$ & $5.4704(1)$ & $5.4686(1)$ & $5.4694(1)$ \\
\hline Carbon content $($ at. $\%)$ & 0.26 & 0.15 & 0.24 \\
\hline
\end{tabular}

\subsection{Dissolution kinetics of these materials}

Dissolution kinetics are reported in figure 3. The dissolution of powders obtained by oxalic route appears similar for both powders. Comparing these data to the SEM micrographs, porosity is likely to promote the penetration of nitric acid at the interface with the solid and to increase the dissolution kinetics. On the contrary, the increase of crystallite sizes could reduce the density of grain boundaries and limit the access of nitric acid, resulting in a decrease of the dissolution kinetics. Up to now, an effect of porosity or crystallite size on the dissolution kinetics was not quantified in the scientific literature. In our study these two effects compensate each other, leading to similar dissolution kinetics for the two $\mathrm{UO}_{2}$ obtained by oxalic route, despite the single and double calcinations. Corollary, no effect of the carbon content on dissolution kinetics could be detected. It is not possible to isolate the role of the carbon content on kinetic dissolution. Finally, the two different synthesis routes conduced to uranium oxides presenting different dissolution kinetics. This result can be attributed to the different morphologies ( size or form of agglomerates, crystallite size, porosity...) exhibited by these uranium oxides.

\section{Conclusion}

To conclude, this study shows that the amount of residual carbon has no significant effect on the $\mathrm{UO}_{2}$ oxide lattice parameters. A large part of this residual carbon has been identified as a graphitic phase presenting crystalline defects. This phase is not homogeneously distributed in the powder which is in agreement with the fact that carbon comes from the disproportionation of carbon monoxide (from the decomposition of oxalate). It has been possible to conclude than a little amount of the carbon may have entered inside the $\mathrm{UO}_{2}$ cell on the basis of the evolution of the microstrain rates. Nevertheless, no quantification was possible. To reduce the carbon content in the powder, an oxidizing/reducing calcination cycle may be applied. However, such a treatment would have an effect on the morphology of the final oxide increasing the crystallite size and intergranular porosity. Finally, no effect of the residual carbon on dissolution kinetics could be highlighted. 


\section{Figures}

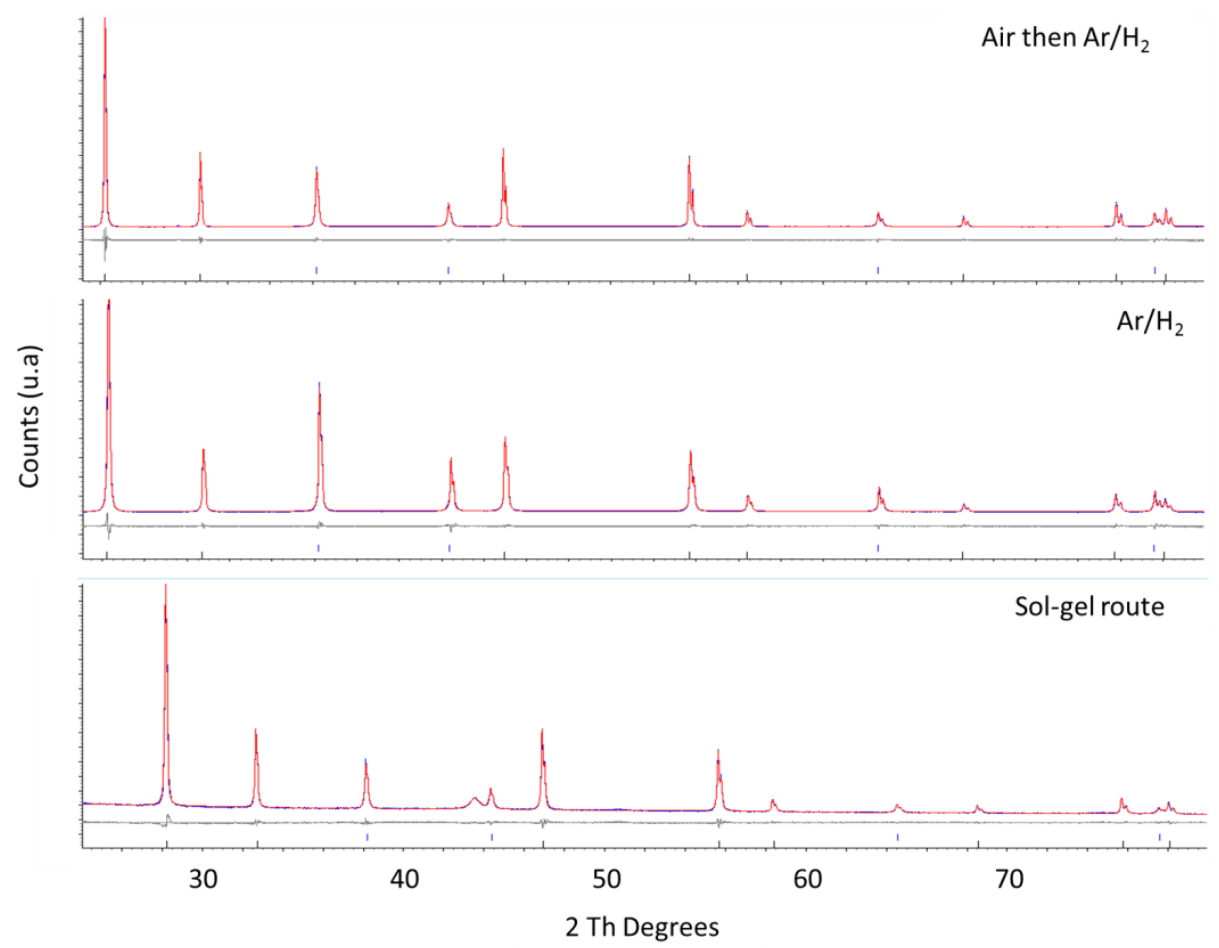

Figure 1 : X-ray diffraction pattern of the three $\mathrm{UO}_{2}$ compounds. The experimental diffractogram (in blue), the calculated diffractogram (in red) and the difference of both diffractogram (in grey) are representing in the figure.

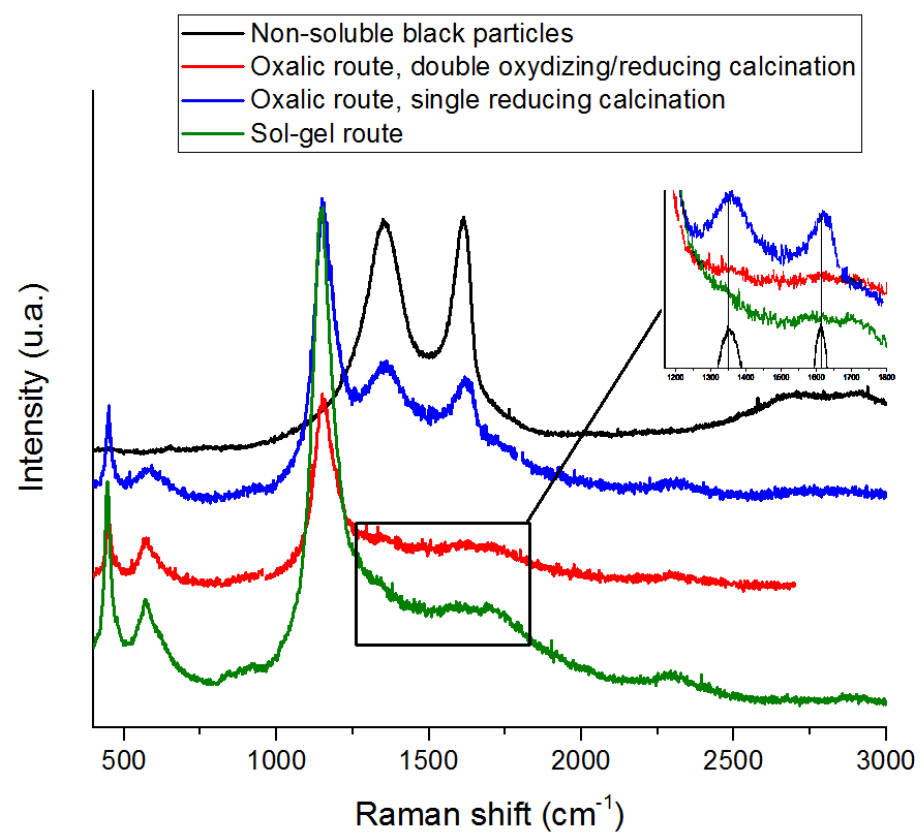

Figure 2: Raman spectroscopy of the three $\mathrm{UO}_{2}$ powders and of the dissolution residues. 


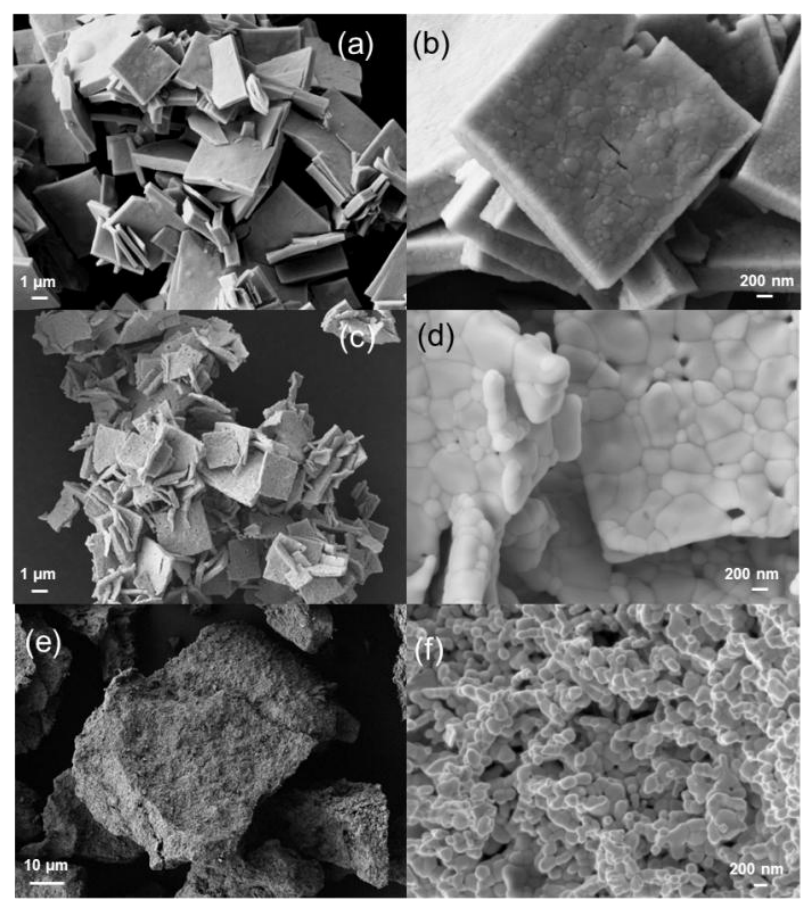

Figure 3: SEM micrographs of $\mathrm{UO}_{2}$ powders in secondary electron mode: (a) and (b) refer to calcination in flowing $\mathrm{Ar} / \mathrm{H}_{2}$, (c) and (d) refers to double cycle of calcination air $+\mathrm{Ar} / \mathrm{H}_{2}$ and (e) and (f) refer to the $\mathrm{UO}_{2}$ obtained by sol-gel route calcined under $\mathrm{Ar} / \mathrm{H}_{2}$.

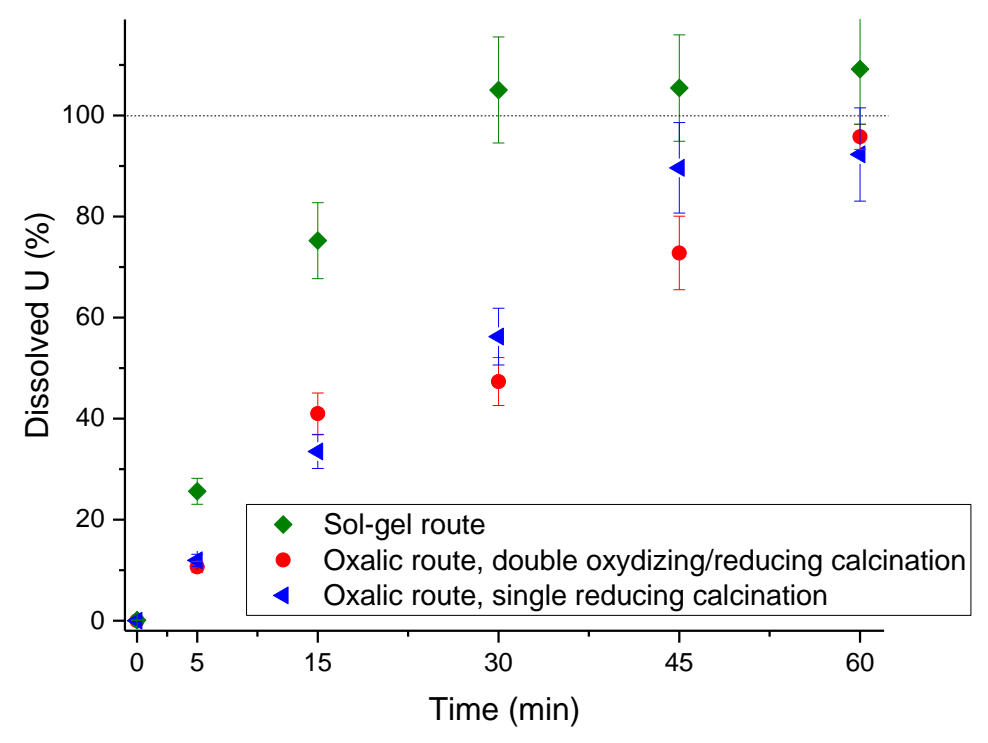

Figure 4: Concentration of uranium dissolved versus time for different calcination atmospheres of $\mathrm{UO}_{2}$ powders.

\section{Acknowledgements}

The authors are thankful to G.Jouan (DRCP/SECA) for SEM imageries. This research was partly funded by AREVA NC, France. The authors specially thank C.Lavalette (AREVA) for encouraging this PhD work and for fruitful discussions. 


\section{References}

${ }^{1}$ Arab-Chapelet B, De Bruycker F, Picart S, Leturcq G, Grandjean S (2008) Structural characterization of mixed uranium-plutonium co-precipitates and oxides synthesized by oxalic co-conversion route. ATALANTE 2008. Montpellier, 19-22 May.

${ }^{2}$ Silver G (2010) Plutonium oxalates as sources of plutonium dioxide. Los Alamos National Laboratory. UR-1002596 NM.

${ }^{3}$ Martinez J, Clavier N, Ducasse T, Mesbah A, Audubert F, Corso B, Vigier N, Dacheux N (2015) From uranium(IV) oxalate to sintered $\mathrm{UO}_{2}$ : Consequences of the powders' thermal history on the microstructure. JECS 35: 4535-4546.

${ }^{4}$ De Almeida L, Grandjean S, Vigier N, Patisson F (2012) Insights into the thermal decomposition of lanthanide(III) and actinide(III) oxalates - from neodymium and cerium to plutonium. European Journal of Inorganic Chemistry 31: 4986-4999.

${ }^{5}$ Grandjean S, Arab-Chapelet B, Robisson A.C, Abraham F, Martin Ph, Dancausse J-Ph, Herlet N, Léorier C (2009) Structure of mixed U(IV)-An(III) precursors synthesized by co-conversion methods (where $\mathrm{An}=\mathrm{Pu}, \mathrm{Am}$ or $\mathrm{Cm}$ ). Journal of Nuclear Materials 385: 204-207.

${ }^{6}$ Hingant N, Clavier N, Dacheux N, Hubert S, Barré N, Podor R, Aranda L (2011) Preparation of morphology controlled $\mathrm{Th}_{1-\mathrm{x}} \mathrm{U}_{\mathrm{x}} \mathrm{O}_{2}$ sintered pellets from low-temperature precursors. Powder Technology 208: 454-460.

${ }^{7}$ Abraham F, Arab-Chapelet B, Rivenet M, Tamain C, Grandjean S (2014) Actinide oxalates, solid state structures and applications. Coordination Chemistry Reviews. Volumes 266-267: 28-68.

${ }^{8}$ Tamain C, Arab-Chapelet B, Rivenet M, Abraham F, Caraballo R, Grandjean S (2013) Crystal growth and first crystallographic characterization of mixed uranium(IV)-plutonium(III) oxalates. Inorganic Chemistry 52: 49414949.

${ }^{9}$ Vaidya V.N (2008) Sol-gel process for ceramic nuclear fuels. Journal of Sol-Gel Science and Technology: 369381.

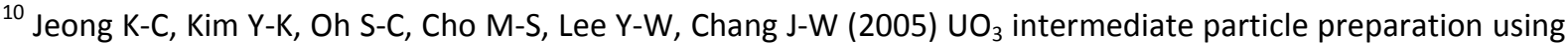
the Sol-gel process. Transactions of the Korean Nuclear Society autumn meeting Busan, Korea, October 27-28.

${ }^{11}$ DIFFRACplus TOPAS/TOPAS R/TOPAS P Version 2.1 and www.bruker-axs.com.

12 Cheary R.W, Coelho A.A, Cline J.P (2004) Fundamental parameters line profile fitting in laboratory diffractometers. J. Res. Natl. Inst. Stand. Technol. 109, 1-25.

${ }^{13}$ Fagerlund G (1973) Determination of specific surface by the BET method. Materials and structures volume 6 : 239-245.

${ }^{14}$ Tyrpekl V, Vigier J-F, Manara D., Wiss T, Dieste Blanco O., Somers J.,(2015) Low temperature decomposition of U(IV) and Th(IV) oxalates to nanograined oxide powders, Journal of Nuclear Materials, 460: 200-208.

${ }^{15}$ Taylor R.F, Sharratt E.W, de Chazel L.E.M, Logsdail D.H (1963) Dissolution rates of uranium dioxide sintered pellets in nitric acid systems. Journal of applied Chemistry 13.

${ }^{16}$ Barbu A, Cojocaru M.O (2013) The cold pressing behavior of uranium dioxide and triuranium octoxide mixed powders. Chemistry and materials science 75: 221-230.

${ }_{17}$ Podor R, Clavier N, Ravaux J, Claparede L, Dacheux N (2012) In Situ HT-ESEM observation of $\mathrm{CeO}_{2}$ grain growth during sintering. Journal of the American Ceramic Society 95: 3683-3690.

${ }^{18}$ Wang Y, Alsmeyer D.C, McCreery R.L (1990) Raman spectroscopy of carbon materials: Structural basis of observed spectra. Chemistry of Material 2: 557-563.

19 Jorio A, Dresselhaus M, Saito R, Dresselhaus G.F (2011) Raman spectroscopy in graphene related systems. Ed Wiley-VCH.

${ }^{20}$ Raza H (2012) Graphene nanoeletronics - Metrology, synthesis, properties and applications. NanoScience and Technology. ISSN $1434-4904$.

${ }^{21}$ Yan Z, Barron A.R (2010) Characterization of graphene by Raman spectroscopy. Open Stax-CNX module: m34667.

${ }^{22}$ Childres I, Jauregui L.A, Park W, Cao H, Chen Y.P (2013) New developments in photon and materials research. Chap 19 : Raman spectroscopy of graphene and related materials. Ed. J.I. Jang.

${ }^{23}$ Ferrari A.C, Meyer J.C, Scardaci V, Casiraghi C, Lazzeri M, Mauri F, Piscanec S, Jiang D, Novoselov K.S, Roth S, Geim A.K (2006) Raman spectrum of graphene and graphene layers. Physical Review Letters 97. 187401.

${ }^{24}$ Bokobza L, Bruneel J-L, Couzi M (2015) Raman spectra of carbon-based materials (from Graphite to Carbon Black) and of some silicone composites. ISSN 2311-5629 (2015): 77-94.

${ }^{25}$ Glasner A. (1964) Remarks on the thermal decomposition of plutonium (IV) oxalates. Journal of Inorganic and Nuclear Chemistry 26: 1475-1476. 
${ }^{26}$ Allen G.C, Butler I.S, Tuan N.A (1987) Characterisation of uranium oxides by micro-Raman spectroscopy. Journal of Nuclear Materials 144: 17-19.

${ }^{27}$ Manara D, Renker B (2003) Raman spectra of stoichiometric and hyperstoichiometric uranium dioxide, Journal of Nuclear Materials 321: 233-237.

${ }^{28}$ Desgranges L, Guimbretière G, Simon P, Jegou C, Caraballo R(2013) A possible new mechanism for defect formation in irradiated $\mathrm{UO}_{2}$. Nuclear Instruments and Methods in Physics. Beam interactions with materials and atoms 315: 169-172.

${ }^{29}$ Livneh T, Sterer E (2006) Effect of pressure on the resonant multiphonon Raman scattering in $\mathrm{UO}_{2}$. Physical Review B 73. Issue 8. 085118.

${ }^{30} \mathrm{He} \mathrm{H}$, Shoesmith D (2010) Raman spectroscopic studies of defect structures and phase transition in hyperstoichiometric $\mathrm{UO}_{2+\times}$. Physical Chemistry Chemical Physics 12: 8109-8118.

${ }^{31}$ Anderson G.R (1977) The Raman spectra of carbon dioxide in liquid $\mathrm{H}_{2} \mathrm{O}$ and $\mathrm{D}_{2} \mathrm{O}$, The journal of physical chemistry 81, 273-276.

${ }^{32}$ Ganguly C, Jayaraj R.N (2004) Characterisation and quality control of nuclear fuels. ISBN 81-7764-608-7.

${ }^{33}$ Mukhtar M, Munisa L, Saleh R (2012) Co-precipitation synthesis and characterization of nanocrystalline zinc oxide particles doped with $\mathrm{Cu}^{2+}$ ions. Materials Sciences and Applications Vol $3 \mathrm{n}^{\circ} 8$ : 546-551.

${ }^{34}$ Pakharukova V.P, Moroz E.M, Kriventsov V.V, Zyuzin D.A, Kosmambetova G.R, Strizhak P.E (2009) Coppercerium oxide catalysts supported on monoclinic zirconia: Structural features and catalytic behavior in preferential oxidation of carbon monoxide in hydrogen excess. Applied Catalysis A: General Vol 365, Issue 2: 159-164. 